\title{
Seasonality and moisture regime control soil respiration, enzyme activities, and soil microbial biomass carbon in a semi-arid forest of Delhi, India
}

\author{
Urvashi Tomar and Ratul Baishya* (D)
}

\begin{abstract}
Soil respiration, soil enzymes, and microbial biomass are important in carbon cycling in the terrestrial ecosystem which is generally limited by environmental factors and soil carbon availability. Hence, we tried to assess the factors affecting the functional aspects of these processes in a semi-arid climate. We monitored soil respiration (surface) using a portable infrared gas analyzer (Q-Box SR1LP Soil Respiration Package, Qubit Systems, Canada) equipped with a soil respiration chamber (Model: G 180). Soil respiration was measured at midday during each season throughout the study period. Soil enzymatic activities and microbial biomass carbon (MBC) were analyzed following the standard protocol for a year during peak time in four seasons at $0-10 \mathrm{~cm}$ and $10-20 \mathrm{~cm}$ depth. Soil respiration shows significant variation with highest in monsoon $\left(3.31 \mu \mathrm{mol} \mathrm{CO} \mathrm{m}^{-2} \mathrm{~s}^{-1}\right)$ and lowest in winter $\left(0.57 \mu \mathrm{mol} \mathrm{CO}_{2}\right.$ $\left.\mathrm{m}^{-2} \mathrm{~s}^{-1}\right)$. Similarly, $\beta$-glucosidase, dehydrogenase, and phenol oxidase activity ranged from 11.15 to $212.59 \mu \mathrm{g}$ PNP $\mathrm{g}^{-1} \mathrm{DW} \mathrm{h}^{-1}, 0.11$ to $16.47 \mu \mathrm{g} \mathrm{TPF} \mathrm{g}{ }^{-1} \mathrm{DW} \mathrm{h} \mathrm{h}^{-1}$, and 4102.95 to $10187.55 \mu \mathrm{mol} \mathrm{ABTS}^{+} \mathrm{g}^{-1} \mathrm{DW} \mathrm{min}^{-1}$, respectively. MBC ranged from 17.08 to $484.5 \mu \mathrm{g} \mathrm{C} \mathrm{g}{ }^{-1}$. Besides, soil respiration, soil enzymes (except $\beta$-glucosidase), and MBC were significantly correlated with soil moisture. Seasonality, optimum moisture and temperature played a significant role in determining variations in soil microbiological processes (except $\beta$-glucosidase activity); the carbon cycling in the study area is assisted by enzyme activity; dehydrogenase and phenol oxidase played a significant role in soil respiration; hence, this landscape is sensitive to environmental changes.
\end{abstract}

Keywords: Soil respiration, Enzyme activities, Microbial biomass carbon, Seasons, Semi-arid forest

\section{Background}

Soil respiration accounts for the largest potential source of atmospheric carbon; hence, even small changes in soil respiration can increase or decrease the atmospheric carbon dioxide level (Schimel 1995). Soil respiration is carbon dioxide emission from soil surface which controls the primary carbon cycle in ecosystems (Jin et al. 2007). Soil respiration consists of two components, namely, autotrophic and heterotrophic respiration. Autotrophic respiration is carbon dioxide released from plant roots whereas

\footnotetext{
* Correspondence: rbaishya@botany.du.ac.in

Ecology \& Ecosystem Research Laboratory, Department of Botany, University of Delhi, Delhi 110007, India
}

\section{Springer Open}

heterotrophic respiration is carbon dioxide released from microbial activity associated with soil organic matter decomposition and constitute $54 \%$ of total respiration in the forest (Hanson et al. 2000; Ryan and Law 2005; Wei et al. 2015). Photosynthesis and heterotrophic respiration are the key processes that regulate terrestrial carbon balance (Xu et al. 2018). Soil heterotrophic respiration and decomposition are mainly associated with the microbial activity (Hanson et al. 2000). Soil enzymes catalyze many important biological processes involved in enhancing the rate of soil metabolism and promote the circulation of nutrient elements (Li et al. 2018).

(c) The Author(s). 2020 Open Access This article is licensed under a Creative Commons Attribution 4.0 International License, which permits use, sharing, adaptation, distribution and reproduction in any medium or format, as long as you give appropriate credit to the original author(s) and the source, provide a link to the Creative Commons licence, and indicate if changes were made. The images or other third party material in this article are included in the article's Creative Commons licence, unless indicated otherwise in a credit line to the material. If material is not included in the article's Creative Commons licence and your intended use is not permitted by statutory regulation or exceeds the permitted use, you will need to obtain permission directly from the copyright holder. To view a copy of this licence, visit http://creativecommons.org/licenses/by/4.0/. 
The soil has a major role in the fertility and stability of forest ecosystems (Smith et al. 1992). Micro-organisms present in soil are responsible for decomposition and conversion of organic matter for vegetation development and plant growth (Aguilera et al. 1999). Soil microbial biomass can act as a source or sink of available nutrients (Singh et al. 1989) and changes in microbial biomass also affect soil organic matter turnover (Yang et al. 2010). The main component of soil microbial biomass is microbial biomass carbon $(\mathrm{MBC})$, it is responsible for controlling the carbon and nutrient flows in ecological systems (Ross et al. 1995; Shao et al. 2015). Living microbial biomass carbon and dead microbial biomass both contributes to microbial biomass carbon pool (Xu et al. 2018). Necromass of dead micro-organisms represents a huge amount of carbon in soil and can act as a readily available source of carbon for living micro-organisms (Xu et al. 2018).

It is well known that the accumulation and decomposition of soil organic carbon (SOC) has a direct effect on carbon storage in the terrestrial ecosystem and global carbon balance (Liu et al. 2016). Hence, soil microbial properties such as soil respiration, enzyme activity, and microbial biomass are considered important in predicting SOC dynamics in many recent studies (Lawrence et al. 2009; Davidson et al. 2012; Wieder et al. 2013; Wei et al. 2015; Memoli et al. 2017; Panico et al. 2020). Various studies have shown seasonal variation in soil respiration (Borken et al. 2003; Huxman et al. 2004; Xu et al. 2004; Jin et al. 2007; Placella et al. 2012; Salazar et al. 2018; Meena et al. 2020), soil enzyme activity (Boerner et al. 2005; Bastida et al. 2008; Hedo et al. 2015), and soil microbial biomass carbon (Singh et al. 1989; Maithani et al. 1996; Bohlen et al. 2001; Ruan et al. 2004; Feng et al. 2009) in the various forest ecosystem. Previous studies of Arunachalam and Arunachalam (2000), Barbhuiya et al. (2004), and Mori et al. (2016) have reported seasonal variation in $\mathrm{MBC}$ in the sub-tropical broad-leaved forest, wet-tropical forest and tropical savannah, respectively. However, studies reporting the same in semi-arid forests are still lacking. Also, seasonal effect considering the association of soil respiration, and enzyme activity with soil $\mathrm{MBC}$ remain uncertain in semi-arid conditions. SOC is mainly recognized as a driving factor that regulates soil microbial growth (Wardle 1992). Soil respiration mainly depends on the concentration, composition, and rate of supply of carbon substrates in the soil solution to the microbial community which is responsible for soil respiration (Van Hees et al. 2005; Iqbal et al. 2010). Also, to evaluate the effect of management on soil respiration in forest ecosystems, soil microbial community and its dynamics should be given much attention (Qi and Yang 2017).

In arid and semi-arid ecosystems strong seasonal precipitation and cycles of drying and rewetting are predominant (Austin et al. 2004). The irregular rainfall pattern in the semi-arid region can create drying and wetting stresses in forest soils (Fierer and Schimel 2002). Hence in such ecosystems, soil microbes are highly sensitive to water impulse and precipitation which results in soil organic carbon decomposition initiation, thereby leading to a cascade of various responses (Carbone et al. 2011; Xu et al. 2018). Since the beginning of the twentieth century, changes in precipitation, temperature, and extreme climatic events have been observed (Milly et al. 2002; Peterson et al. 2002), simultaneously, rainfall event was also found to be less frequent and more extreme (Stocker 2014). Variability in monsoon rainfall is observed in the country (Mall et al. 2006) which will develop a threat for tropical soils in the Indian subcontinent (Bhattacharyya et al. 2000). As the future climate is predicted to be more extreme even in the case of the semi-arid condition, the data on such conditions would be more important. Thus, to predict the future of carbon cycle and their potential to sequester carbon in the soil in the changing world, we need to understand the seasonal changes in the processes that play important role in carbon cycling (i.e., soil respiration, enzyme activity, and soil $\mathrm{MBC}$ ).

The study was conducted in the National Capital Territory (NCT) of Delhi which has a scattered forest cover and investigations on soil respiration, enzyme activity, and $M B C$ are very limited. Since these studies are essential for understanding carbon cycling, hence, creating management policies to maximize the sequestration of carbon in the soil becomes necessary. The data gap in the semi-arid forest of India compelled us to investigate whether the soil respiration, enzyme activities, and MBC were influenced by seasonal changes in the semi-arid climate. Our study also discussed the relationship between SOC and the above factors to provide a theoretical basis for further understanding of the carbon cycling in semiarid forests of India.

\section{Materials and methods Study site}

Our study sites are Delhi Ridges which are fragmented forest patches and scattered into four ridges, viz., Southern Ridge, Central Ridge, South-Central Ridge, and Northern Ridge occupying an area of 6200, 864, 626, and $87 \mathrm{ha}$, respectively. Out of the total geographical area of $1483 \mathrm{~km}^{2}$, the forest cover of the state is 192.41 $\mathrm{km}^{2}$ which is $12.97 \%$ of the total geographical area of Delhi (FSI 2017). The state lies in the northern part of India between $28^{\circ} 24^{\prime} 17^{\prime \prime}-28^{\circ} 53^{\prime} 00^{\prime \prime} \mathrm{N}$ latitudes and $76^{\circ} 45^{\prime} 30^{\prime \prime}-77^{\circ} 21^{\prime} 30^{\prime \prime}$ E longitude. The Delhi Ridge forests are the northern extension of Aravalli hill range and occupy $77.77 \mathrm{~km}^{2}$ of forest cover. The distribution of the four ridges (Tomar and Baishya 2019) is depicted 
in Fig. 1. During June 2016-May 2017, the temperature recorded in the study area varied between 15.6 and $40.5^{\circ} \mathrm{C}$ in January and May, respectively. The annual rainfall recorded was $1285.2 \mathrm{~mm}$ from June 2016-May 2017 (Fig. 2a). The highest rainfall was observed in July and August. The basic soil characteristics of each Delhi Ridge are represented in Table 1.

The dominated species in the Delhi Ridge is Prosopis juliflora which is an exotic tree species introduced by the British regime in 1877 to enhance the vegetation of the region. According to Champion and Seth (1968), Ridge forests are classified as tropical thorn forests. Climate is semi-arid and soil texture is sandy loam. The soil $\mathrm{pH}$ ranged between 6.31 and 7.51. The state witnesses four seasons, namely, pre-monsoon (March to May), monsoon (June to Aug.), post-monsoon (Sept. to Nov.), and Winter (Dec. to Feb.) (Tomar and Baishya 2019).

\section{Soil sampling}

Soil sampling was done for 1 year between June 2016 and May 2017. The soil was collected using a steel soil auger after removing litter from the soil surface in premonsoon, monsoon, post-monsoon, and winter seasons in all four Ridges. Three replicates of five randomly collected sub-samples were collected and homogenized from each ridge in both soil depth, namely, $0-10 \mathrm{~cm}$ and $10-20 \mathrm{~cm}$. Soil samples were collected from near the collars inserted for soil respiration study. Samples were taken to the laboratory in airtight and labeled sampling packets, plant litter, and woody debris were removed and stored at $4{ }^{\circ} \mathrm{C}$ for further analysis.

\section{Soil physico-chemical and microbiological analysis}

Soil moisture was determined within $48 \mathrm{~h}$ of soil collection. Ten grams of fresh soil was dried in an oven at $105^{\circ} \mathrm{C}$ until constant weight. Soil moisture was determined following Allen et al. (1974). Soil temperature was measured using soil thermometer inserted till $10 \mathrm{~cm}$ depth in the soil. Soil organic carbon (SOC) was analyzed by digesting soil with a few drops of hydrochloric acid $(\mathrm{HCl})$. The digested soil was oven dried and SOC content in the digested sample was determined using Liqui TOC II analyzer (Elementar Analysis systems $\mathrm{GmbH}$, Germany). Soil respiration was measured at midday between 11:00 am and 2:00 pm local time, during each season throughout the study period, using a portable infrared gas analyzer (Q-Box SR1LP Soil Respiration Package, Qubit Systems, Canada) equipped with soil respiration chamber (Model: G 180) having a diameter of $10.16 \mathrm{~cm}$ and a volume of $1.0 \mathrm{~L}$. The collars were inserted $1.9 \mathrm{~cm}$ into the soil at each sampling point about two weeks before the first measurement. Litter was removed before the insertion of the chamber. All collars were left at the site for the entire study period. Soil respiration was expressed in $\mu \mathrm{mol} \mathrm{CO}_{2} \mathrm{~m}^{-2} \mathrm{~s}^{-1}$. Soil temperature and moisture were measured near each collar at the same time as soil respiration. Soil $\beta$ glucosidase activity (BA) indicates the state of organic matter and decomposition activity in the soil (Garcia

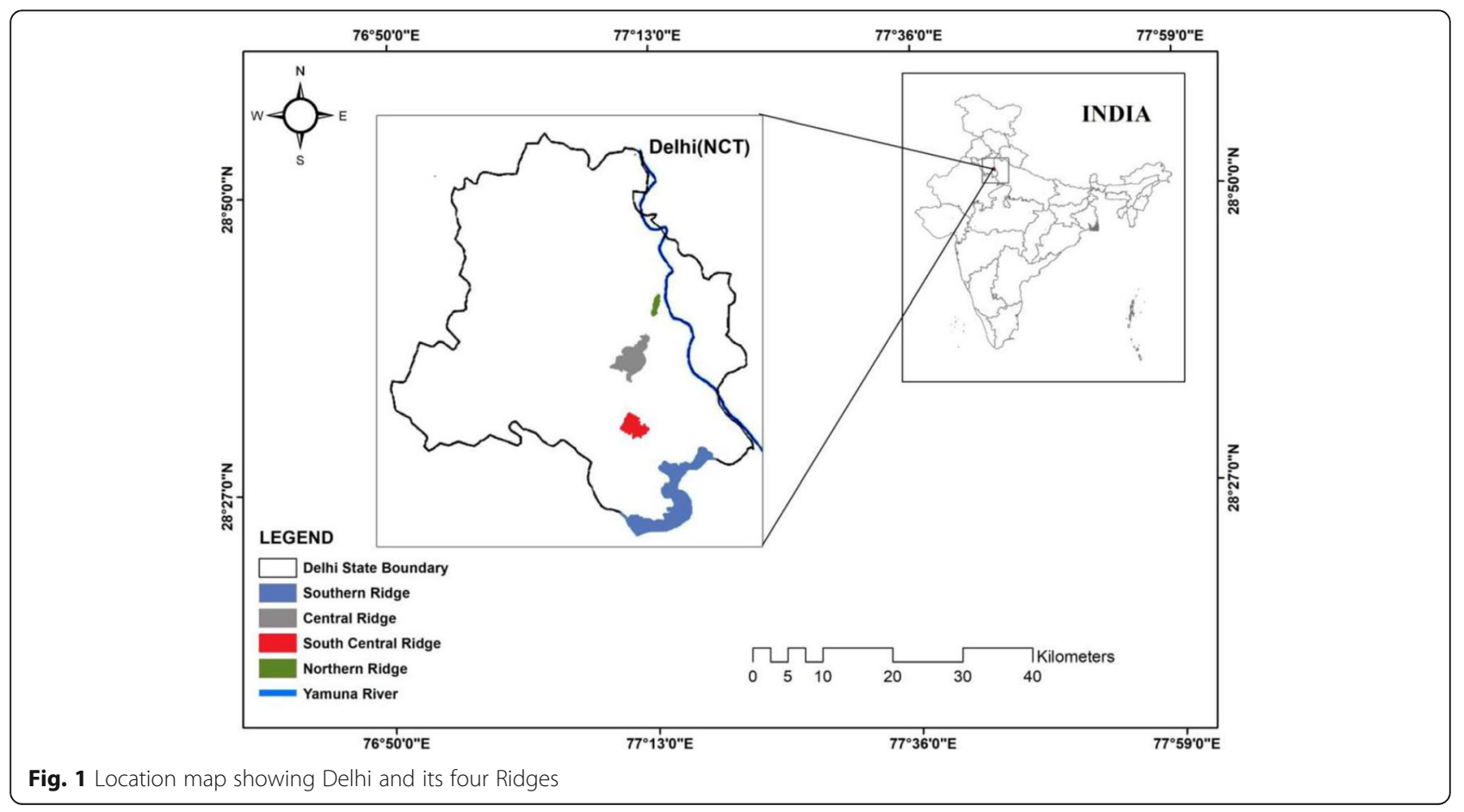



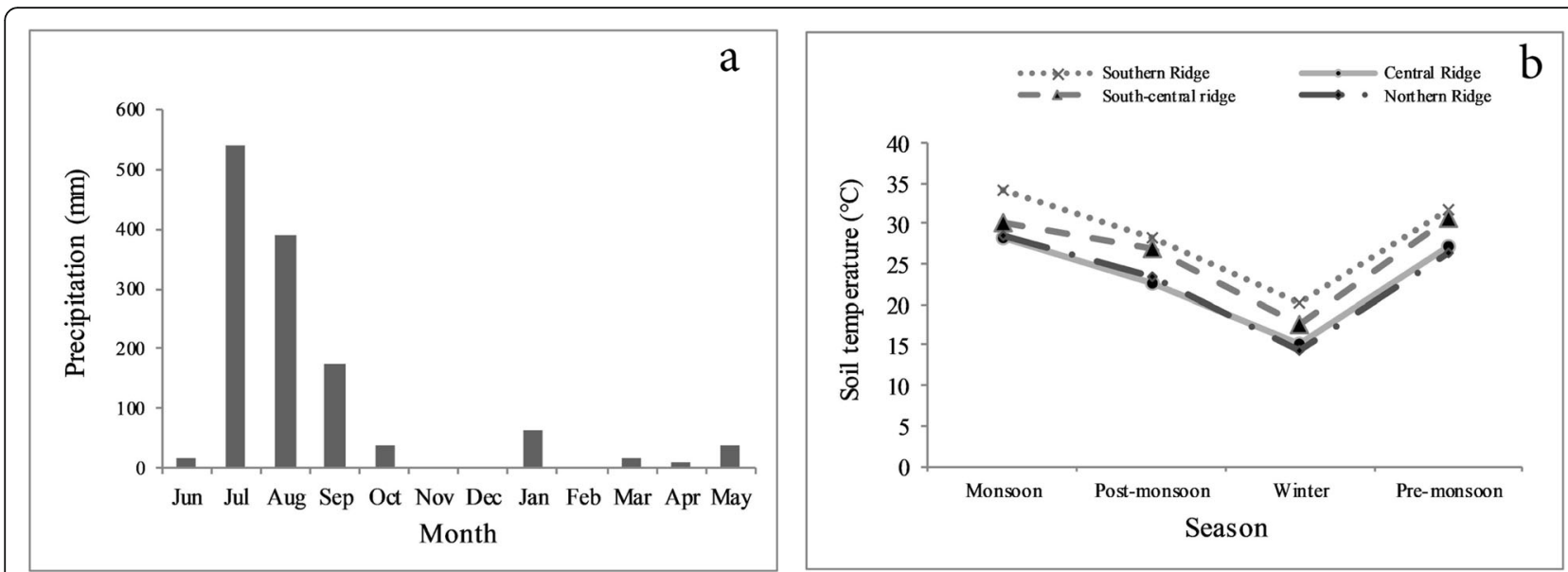

Fig. 2 (a) Annual variation in precipitation ( $\mathrm{mm}$ ) (source: Agromet, IARI, Delhi) and (b) seasonal variation in soil temperature $\left({ }^{\circ} \mathrm{C}\right)$ during sampling year (June 2016-May 2017) in Delhi

et al. 1994; Wang et al. 2014). It was assayed using pnitrophenyl- $\beta$-D-glucoside (PNG) (Eivazi and Tabatabai 1988). One gram of field moist $2 \mathrm{~mm}$ sieved soils was taken in a $50 \mathrm{ml}$ conical flask. To this $250 \mu \mathrm{l}$ of toluene, $4 \mathrm{ml}$ of modified universal buffer ( $\mathrm{pH} \mathrm{6}$ ) and $1 \mathrm{ml}$ of 25 mM p-nitrophenyl- $\beta$-D-glucoside was added. The blank flask did not get a PNG solution. The flask was swirled, covered with stopper, and incubated at $37^{\circ} \mathrm{C}$ for $1 \mathrm{~h}$. Following incubation time $1 \mathrm{ml}$ of $0.5 \mathrm{M} \mathrm{CaCl}_{2}$ and $4 \mathrm{ml}$ of $0.1 \mathrm{M}$ THAM (tris-hydroxymethyl aminomethane), $\mathrm{pH} 12$ was added. The contents were filtered using Whatman filter paper no. 2. Before filtering the blanks, $1 \mathrm{ml}$ of PNG was added. Finally, the absorbance of pnitrophenol (PNP) released was determined using a spectrophotometer at $400 \mathrm{~nm}$. The concentration of PNP was estimated using a PNP standard calibration curve. Results were expressed as $\mu \mathrm{g}$ PNP $\mathrm{g}^{-1} \mathrm{DW} \mathrm{h}{ }^{-1}$. Soil dehydrogenase activity (DHA) reflects the metabolic activity in the soils (Wolinska and Stępniewska 2012). It was determined using 2,3,5-triphenyltetrazolium chloride (TTC) reduction assay (Casida 1977). Six grams of field moist $2 \mathrm{~mm}$ sieved soil was taken in a glass tube $(15 \times 150 \mathrm{~mm})$. To this, $0.06 \mathrm{~g}$ of $\mathrm{CaCO}_{3}$ was added along with $1 \mathrm{ml}$ of $3 \%$ TTC solution. Blanks were also created for each soil sample where TTC was not added. The total volume of fluids was made to $3.5 \mathrm{ml}$ (i.e., 3.5 $\mathrm{ml}$ autoclaved DI water in blanks and $2.5 \mathrm{ml}$ in samples).
All the tubes were sealed using parafilm, starred, and incubated at $37^{\circ} \mathrm{C}$ for $24 \mathrm{~h}$ in dark. Following incubation time, soil samples were transferred with methanol into a 50-ml graduated cylinder through Whatman filter paper no. 5. The red methanolic extract of tri-phenyl formazan (TPF) was determined using a spectrophotometer at 485 $\mathrm{nm}$ against soil banks. The concentration of TPF was estimated using a TPF standard calibration curve. Results were expressed as $\mu \mathrm{g}$ TPF $\mathrm{g}^{-1} \mathrm{DW} \mathrm{h}^{-1}$. Soil phenol oxidase activity (PO) indicates oxidation of complex organic compounds like lignin during decomposition (Luo and $\mathrm{Gu}$ 2015). It was determined using the ABTS assay (Floch et al. 2007). A total of $0.1 \mathrm{~g}$ field moist $2 \mathrm{~mm}$ sieved soil was taken in a $15-\mathrm{ml}$ centrifuge tube and to this $10 \mathrm{ml}$ of MUB solution (pH 2) in $200 \mu \mathrm{l}$ of $0.1 \mathrm{M}$ ABTS (2,2' -azino-bis(3-ethylbenzothiazoline-6-sulphonic acid)) solution was added. The mixture was incubated at $30{ }^{\circ} \mathrm{C}$ for $5 \mathrm{~min}$ in a water bath following which the mixture was centrifuged at $12000 \mathrm{rpm}$ for $2 \mathrm{~min}$ at $4{ }^{\circ} \mathrm{C}$. The oxidation rate to $\mathrm{ABTS}^{+}$was determined in the supernatant at $420 \mathrm{~nm}$. Results were expressed as $\mu \mathrm{mol}$ $\mathrm{ABTS}^{+} \mathrm{g}^{-1} \mathrm{DW} \mathrm{min}^{-1}$. Microbial biomass carbon (MBC) was determined by the fumigation-extraction method (Vance et al. 1987). Ten grams of field moist $2 \mathrm{~mm}$ sieved soil was fumigated with ethanol-free chloroform for $24 \mathrm{~h}$ in a vacuum desiccator and the other $10 \mathrm{~g}$ was not fumigated. Forty milliliter of $0.5 \mathrm{M} \mathrm{K}_{2} \mathrm{SO}_{4}$ solution

Table 1 Basic soil physicochemical properties (mean \pm standard deviation) in the study area

\begin{tabular}{lllll}
\hline Ridge & $\mathrm{pH}$ & Bulk density $\left(\mathrm{g} \mathrm{cm}^{-3}\right)$ & TC (\%) & TN (\%) \\
\hline Southern Ridge & $6.98(0.02)$ & $1.07(0.41)$ & $0.65(0.20)$ & $0.06(0.06)$ \\
Central Ridge & $6.91(0.04)$ & $1.11(0.31)$ & $1.56(0.25)$ & $0.12(0.07)$ \\
South-Central Ridge & $6.94(0.02)$ & $1.06(0.49)$ & $1.09(0.17)$ & $0.11(0.00)$ \\
Northern Ridge & $6.85(0.04)$ & $1.11(0.32)$ & $1.20(0.34)$ & $0.11(0.05)$ \\
\hline
\end{tabular}

$T C$ total carbon; $T N$ total nitrogen 
was used to extract both fumigated and non-fumigated samples. Samples were shaken for $1 \mathrm{~h}$ in a rotary shaker. The extract was filtered using Whatman filter paper no. 42. The carbon content in the filtrate was measured using Liqui TOC II analyzer. MBC was calculated as $\mathrm{MBC}=2.22 \mathrm{Ec}$, where $\mathrm{Ec}$ is organic carbon from fumigated soil-organic carbon extracted from nonfumigated soils (Wu et al. 1990). MBC was expressed as $\mu \mathrm{g} \mathrm{C} \mathrm{g}{ }^{-1}$.

\section{Statistical analysis}

Data were analyzed by two-way ANOVA at which season (monsoon, post-monsoon, winter, and postmonsoon) and soil depth $(0-10 \mathrm{~cm}$ and $10-20 \mathrm{~cm})$ were selected as factors. To determine pair-wise differences by post hoc tests, the data were submitted to one-way ANOVA for each season. Tukey's HSD post hoc test was applied. A $p<0.01$ or 0.05 level of significance was adopted throughout. Pearson's correlation analysis was also carried out by including all the soil microbiological and physical variables measured in the study. The correlation pattern was further examined by principal component analysis (PCA). All the statistical analysis was done using IBM SPSS 16, statistical software.

\section{Results}

\section{Physical and chemical variables}

Soil moisture and temperature both showed significant seasonal variation during the study period $(p<0.01)$. Soil temperature ranged from 14.4 to $34{ }^{\circ} \mathrm{C}$ (Fig. 2b). It was observed highest in pre-monsoon and postmonsoon and lowest in winter. Soil moisture was highest in monsoon and lowest in winter. It ranged from 3.07 to $17.12 \%$ and 2.97 to $12.97 \%$ under $0-10$ and $10-20 \mathrm{~cm}$, respectively in all the Delhi Ridges (Fig. 3a, b). The seasonality of soil moisture coincided with the seasonal pattern of precipitation. Significant seasonal variations were also obtained $(p<0.05)$ in SOC (Table 2$)$, which was highest in winter and lowest in monsoon. SOC varied within the range of 0.84 to $2.04 \%$ and 0.26 to $1.74 \%$ in $0-10$ and $10-20 \mathrm{~cm}$ depth, respectively (Fig. 3c, d). It also showed variations across depths and observed higher values in $0-10 \mathrm{~cm}$ depth (Table 2 ) in all the Delhi Ridges.

\section{Seasonal variation in soil respiration}

The highest soil respiration was observed in the monsoon season when the precipitation was at a peak (Fig. 4). Soil respiration showed significant seasonal variation ( $F$ value: 136.26 and $p<0.01)$ and showed maximum values in monsoon season in all the Delhi Ridges. It ranged from 0.57 to $3.31 \mu \mathrm{mol} \mathrm{CO} \mathrm{CO}_{2} \mathrm{~m}^{-2} \mathrm{~s}^{-1}$. Minimum soil respiration occurred in the winter season as the precipitation is lowest and soil temperature and soil moisture are minimum during the winter season.

\section{Microbiological variables}

Seasons and depth significantly affected all the enzymatic activities except $\beta$-glucosidase, which is affected by depth only. Variations in seasons and depth significantly influenced $(p<0.05)$ dehydrogenase and phenol oxidase (Table 2). The interaction between season and depth was influential for dehydrogenase $(p<0.05)$. $\beta$ glucosidase ranged from 29.14 to $212.59 \mu \mathrm{g}$ PNP $\mathrm{g}^{-1}$ DW $\mathrm{h}^{-1}$ and 11.15 to $123.48 \mu \mathrm{g} \mathrm{PNP} \mathrm{g}^{-1} \mathrm{DW} \mathrm{h}^{-1}$ in 0 $10 \mathrm{~cm}$ and $10-20 \mathrm{~cm}$ depth, respectively (Fig. $5 \mathrm{a}, \mathrm{b}$ ). Dehydrogenase showed higher values in monsoon. It varied from 0.26 to $16.47 \mu \mathrm{g} \mathrm{TPF} \mathrm{g}^{-1} \mathrm{DW} \mathrm{h}^{-1}$ and 0.11 to $8.95 \mu \mathrm{g} \mathrm{TPF} \mathrm{g}^{-1} \mathrm{DW} \mathrm{h}^{-1}$ in $0-10 \mathrm{~cm}$ and $10-20 \mathrm{~cm}$ depth, respectively (Fig. 5c, d). Similarly, phenol oxidase showed higher values in post-monsoon and monsoon season and lower in pre-monsoon and winter seasons. It ranged from 4108.60 to $10187.55 \mu \mathrm{mol} \mathrm{ABTS}^{+} \mathrm{g}^{-1} \mathrm{DW}$ $\mathrm{min}^{-1}$ and 4102.95 to $7393.87 \mu \mathrm{mol} \mathrm{ABTS}{ }^{+} \mathrm{g}^{-1} \mathrm{DW}$ $\mathrm{min}^{-1}$ in $0-10 \mathrm{~cm}$ and $10-20 \mathrm{~cm}$ depth, respectively (Fig. $5 e, f)$.

Soil MBC showed clear significant $(p<0.05)$ seasonal variation during the study period (Table 2). Soil MBC varied with seasons and ranged from 49.88 to $484.52 \mu \mathrm{g}$ $\mathrm{C} \mathrm{g}^{-1}$ and 17.08 to $358 \mu \mathrm{g} \mathrm{C} \mathrm{g}{ }^{-1}$ in $0-10$ and $10-20 \mathrm{~cm}$ depth, respectively (Fig. 6a, b) in all the Delhi Ridges. MBC was highest in monsoon season and lowest in the winter season. MBC also showed significant $(p<0.05)$ variation among the two depths and was observed higher in $0-10 \mathrm{~cm}$ than in $10-20 \mathrm{~cm}$ depth (Table 2).

\section{Correlation analysis}

A positive significant correlation was observed between MBC and other studied soil microbiological and physical variables (dehydrogenase, phenol oxidase, soil respiration, soil temperature, and soil moisture). $\mathrm{MBC}$ was observed to be negatively correlated with SOC (Table 3). Soil respiration showed a positive correlation with $\mathrm{MBC}$, dehydrogenase, phenol oxidase, soil temperature, and soil moisture. $\beta$-glucosidase showed a significant positive correlation with SOC. However, it was not correlated with other microbiological and physical factors (Table 3). Dehydrogenase showed a positive significant correlation with respiration, $\mathrm{MBC}$, and soil moisture, while a negative correlation was observed with SOC (Table 3). Phenol oxidase showed a positive correlation with $\mathrm{MBC}$, soil respiration, soil temperature, and soil moisture, but a negative correlation was observed with $\mathrm{SOC}$ and $\beta$ glucosidase. In $10-20 \mathrm{~cm}$ depth, correlation patterns were found to be similar except for a negative correlation and no correlation of $\beta$-glucosidase and phenol oxidase was observed with soil temperature (Table 3). 

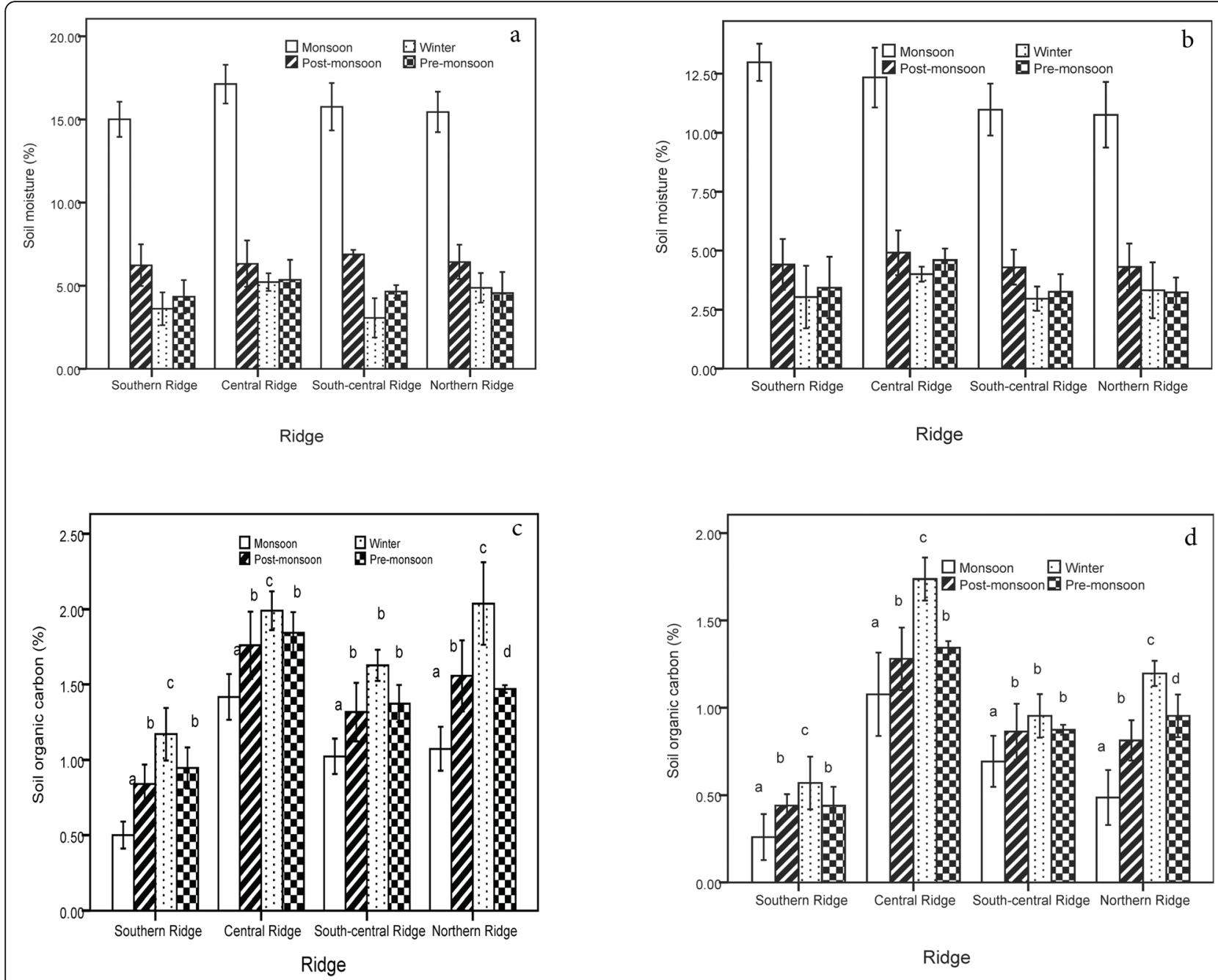

Fig. 3 Seasonal variation in soil moisture (\%) (a) 0-10 cm depth and (b) $10-20 \mathrm{~cm}$ depth and soil organic carbon (\%) (c) 0-10 cm depth, (d) $10-$ $20 \mathrm{~cm}$ depth under all seasons in all the Delhi Ridges. Bars indicate standard error of the mean. Different letters represent significant differences among different seasons in all the Delhi Ridges ( $p<0.05$; Tukey post hoc test)

Table 2 Results of two-way ANOVA (season and depth) for microbiological variables

\begin{tabular}{lllllll}
\hline & Df & \multicolumn{6}{l}{$F$ value } & & \\
\cline { 3 - 7 } & & BA & DHA & PO & MBC & SOC \\
\hline Season & 3 & 2.08 & $57.38^{* *}$ & $18.61^{* *}$ & $92.80^{* *}$ & $11.33^{* *}$ \\
Depth & 1 & $26.30^{* *}$ & $15.38^{* *}$ & $4.01^{*}$ & $58.55^{* *}$ & $44.56^{* *}$ \\
Se $\times$ dp & 3 & 0.23 & $6.44^{* *}$ & 0.77 & $5.79^{* *}$ & 0.46 \\
\hline
\end{tabular}

$\mathrm{d} f$ degree of freedom; Se season; $d p$ depth; se $\times d p$ interaction season and depth; $B A$ $\beta$-glucosidase activity; $D H A$ dehydrogenase activity; $P O$ phenol oxidase activity; $M B C$ microbial biomass carbon; $S O C$ soil organic carbon $n=12$

${ }^{*} p<0.05$

${ }^{* *} p<0.01$
The principal component analysis (PCA) was carried out on all the studied soil microbiological and physical variables as factors and the analysis revealed that two principal components with eigenvalue more than one are responsible for the variance observed in the studied factors. The component contributing to maximum variance becomes the first PC (principal component) and others become the second PC. In $0-10 \mathrm{~cm}$ depth, the PCA axis F1 (Fig. 7a) accounted for $56.17 \%$ of total variation among the studied soil parameters and the loadings values are 0.961 (soil respiration), 0.903 (soil moisture), 0.849 (MBC), -0.736 (SOC), 0.724 (soil temperature), 0.716 (DHA), 0.643 (PO), and -0.203 (BG) while PCA axis F2 accounted for $22.25 \%$ variation with loading values: 0.868 (BG), 0.618 (SOC), 0.583 (DHA), 0.337 (MBC), -0.366 (PO), 0.287 (soil moisture), -0.223 (soil temperature), and 0.067 (soil respiration). Similarly, in 


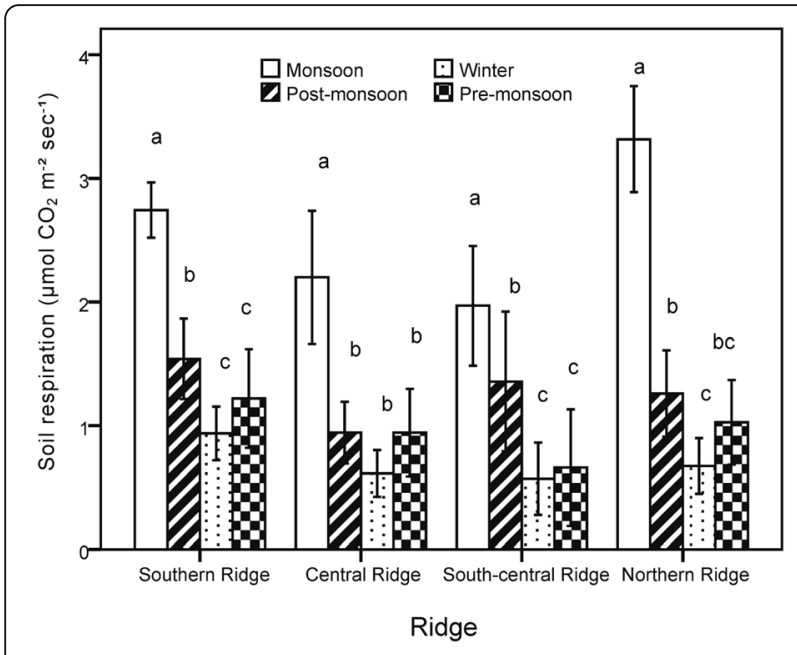

Fig. 4 Seasonal variation in soil respiration $\left(\mu \mathrm{mol} \mathrm{CO}_{2} \mathrm{~m}^{-2} \mathrm{~s}^{-1}\right)$ under all seasons in all the Delhi Ridges. Bars indicate standard error of the mean. Different letters represent significant differences among different seasons in all the Delhi Ridges $(p<0.05$; Tukey post hoc test)

10-20 cm depth, the PCA axis F1 (Fig. 7b) accounted for $54.17 \%$ of total variation among the studied soil parameters and the loadings values are 0.960 (soil respiration), 0.879 (soil moisture), 0.869 (MBC), 0.709 (DHA), 0.699 (soil temperature), -0.638 (SOC), 0.597 (PO), and -0.358 (BG) while PCA axis F2 accounted for $22.63 \%$ variation with loading values: 0.817 (BG), and 0.642 (SOC), 0.610 (DHA), 0.364 (MBC), -0.324 (PO), 0.243 (soil moisture), -0.227 (soil temperature), 0.096 (soil respiration).

\section{Discussion}

Our study indicated that studied soil microbiological activity and $\mathrm{MBC}$ showed a clear seasonal pattern in all the Delhi Ridges. Soil respiration showed clear seasonal variation and was highest in monsoon season and lowest in winter season. The seasonal pattern of soil respiration was as per previous findings of Tang et al. (2006) and Meena et al. (2020), suggesting that seasonal changes in soil respiration are correlated with soil moisture and soil temperature. Lou et al. (2004) showed a correlation of soil respiration, soil moisture, and $\mathrm{MBC}$. Additionally, we observed the correlation of soil respiration with the above factors as well as with enzyme activity (dehydrogenase and phenol oxidase). High soil respiration during monsoon is attributed due to an increase in microbial activity during the rewetting of soil after a period of drying (Salazar et al. 2018). The microbial activity utilizes $C$ from $\mathrm{SOC}$ and releases it in the atmosphere in the form of $\mathrm{CO}_{2}$ resulting in an increase in $\mathrm{C}$ emission from soil to atmosphere, thereby decreasing the soil $\mathrm{C}$ storage (Wang et al. 2013). Soil temperature and moisture directly or indirectly affect respiration-related enzyme activity by affecting the supply of the substrates (Kishimoto-Mo et al. 2015).

Soil enzymes have a major role in biochemical processes occurring in the soil environment as they are the core mediators of organic matter decomposition, nutrient cycling, and energy transfer (Shao et al. 2015). In the present study, dehydrogenase and phenol oxidase activity showed significant seasonal variation but $\beta$-glucosidase activity did not show any variation concerning the seasons. Every enzyme is characterized by its substrate and ability to catalyze specific biochemical reactions (Song et al. 2012). $\beta$-glucosidase activity catalyzes the hydrolysis of $\beta$-glucosides, thereby producing glucose and thus the enzyme complex is involved in the decomposition of plant remains (Hayano and Tubaki 1985). According to Baldrian et al. (2010), enzyme activities in forest soils show seasonal variation. However, in our study $\beta$-glucosidase activity did not show seasonal variations and correlation with soil moisture. Similar results were also obtained by Hedo et al. (2015) in semi-arid dry forest strands. The activity of $\beta$-glucosidase is likely to be controlled by organic matter in the soil and the varying inputs of the litter with a season do not affect the activity of this enzyme (Wick et al. 2002). We obtained a positive significant correlation $(r=0.64, p<$ 0.01 ) of $\beta$-glucosidase with SOC (Table 3), as the enzyme mainly participates in mineralization and cycling of carbohydrates in the soil (Wick et al. 2002). It is involved in the hydrolytic conversion of cellulose as a fraction of soil organic matter pool rather than total carbon (Wick et al. 2002). Positive correlations of $\beta$-glucosidase with organic $\mathrm{C}$ was also reported by Eivazi and Tabatabai (1990) and Wick et al. (2002). The activity of dehydrogenases is fundamental part of enzymes system occurring in living organisms because of the involvement of several dehydrogenases in the respiratory pathway (Wolinska and Stępniewska 2012). Dehydrogenase activity is intracellular and the enzyme complex participates in the transfer of electrons (Nannipieri et al. 1990). Dehydrogenase activity serves as an indicator of microbial activity in such semi-arid soils (Ros et al. 2003), this can be observed from a positive correlation between $\mathrm{MBC}$ and dehydrogenase activity in our study, as when the number of microbes increases, production of dehydrogenase enzyme also increases. With significant seasonal variation, dehydrogenase activity was found higher in monsoon season suggesting that soil moisture has a significant role in the production of dehydrogenase enzyme. The survival and the activity of soil microorganisms are known to be impacted by the availability of water (Uhlirova et al. 2005). Low water availability results in lowering of intracellular water potential, thereby reducing hydration, and inhibiting microbial activity 

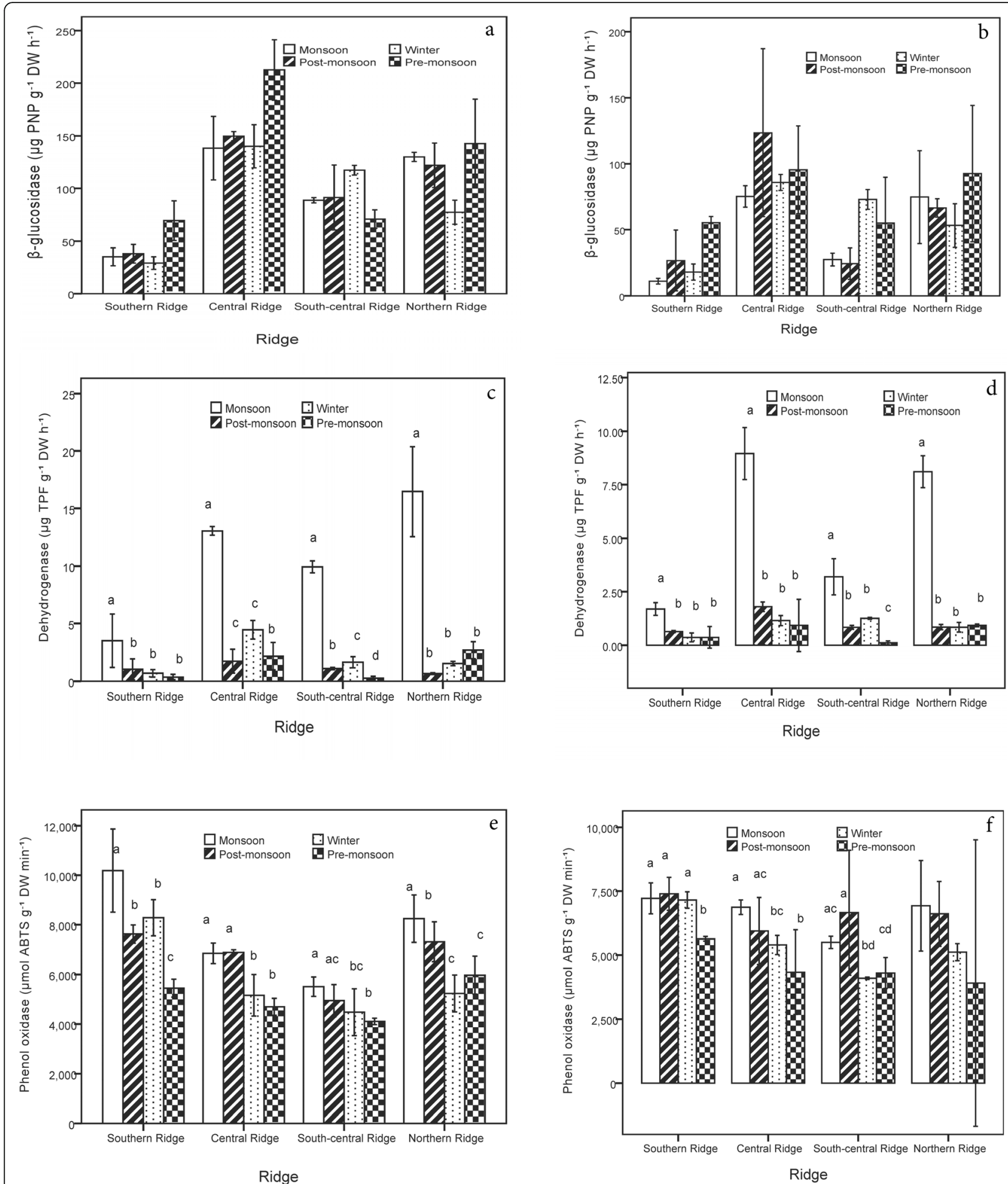

Fig. 5 Seasonal variations in $\beta$-glucosidase activity $\left(\mu \mathrm{g}\right.$ PNP $\left.\mathrm{g}^{-1} \mathrm{DW} \mathrm{h}^{-1}\right)(\mathbf{a})$ 0-10 $\mathrm{cm}$ depth, (b) $10-20 \mathrm{~cm}$ depth; dehydrogenase activity $(\mu \mathrm{g}$ TPF $\mathrm{g}^{-1} \mathrm{DW} \mathrm{h}^{-1}$ ) (c) 0-10 cm depth, (d) $10-20 \mathrm{~cm}$ depth and phenol oxidase activity (umol ABTS $\mathrm{g}^{-1} \mathrm{DW} \mathrm{min}^{-1}$ ) (e) $0-10 \mathrm{~cm} \mathrm{depth,} \mathrm{(f)} 10-20 \mathrm{~cm}$ depth under all seasons in all the Delhi Ridges. Bars indicate standard error of the mean. Different letters represent significant differences among different seasons in all the Delhi Ridges ( $p<0.05$; Tukey post hoc test) 

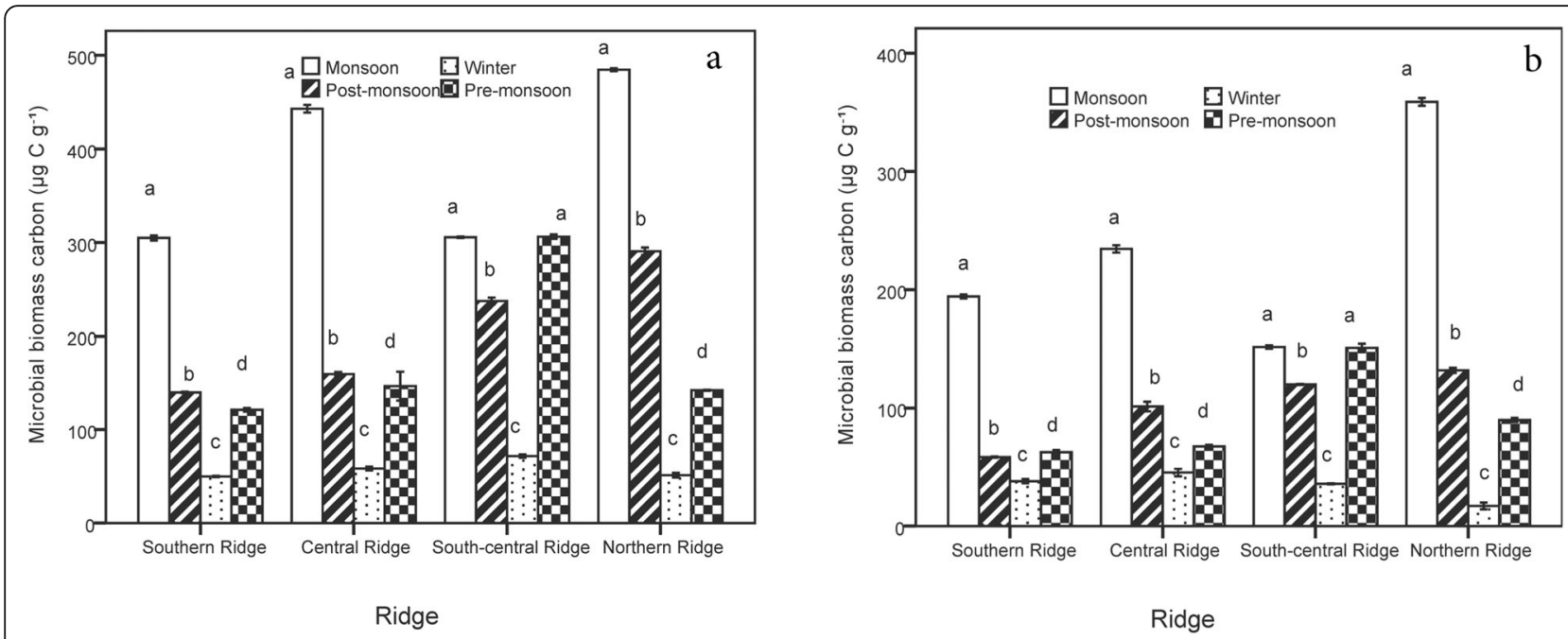

Fig. 6 Seasonal variation in microbial biomass carbon $(\mu \mathrm{g} \mathrm{C} \mathrm{g}$ ) (a) $0-10 \mathrm{~cm}$ depth, (b) $10-20 \mathrm{~cm}$ depth under all seasons in all the Delhi Ridges. Bars indicate standard error of the mean. Different letters represent significant differences among different seasons in all the Delhi Ridges $(p<$ 0.05; Tukey post hoc test)

(Wall and Heiskanen 2003). Microbial communities suffer starvation during periods of moisture limitation; hence, the drought stress is considered as the most common environmental stress for soil microorganisms (Wolinska and Stępniewska 2012). As the activities of dehydrogenases in different forest ecosystems are involved in C cycling (Salazar et al. 2011), thus, dehydrogenases are associated with microbial biomass and affects the decomposition of organic matter which is reflected by high soil respiration (Zhang et al. 2010). Hence, we observed a positive significant correlation between dehydrogenase activity and soil respiration.

Table 3 Pearson's correlation matrix between soil parameters at $0-10 \mathrm{~cm}$ and $10-20 \mathrm{~cm}$ depth

\begin{tabular}{|c|c|c|c|c|c|c|c|c|}
\hline & RESP & $\mathrm{BA}$ & $\mathrm{DHA}$ & $\mathrm{PO}$ & $\mathrm{MBC}$ & SOC & ST & SM \\
\hline \multicolumn{9}{|c|}{$0-10 \mathrm{~cm}$} \\
\hline RESP & 1 & -0.13 & $0.74^{* *}$ & $0.66^{* *}$ & $0.79 * *$ & $-0.66^{* *}$ & $0.61^{* *}$ & $0.88^{* *}$ \\
\hline BA & & 1 & 0.25 & $-0.38^{* *}$ & 0.10 & $0.64^{* *}$ & -0.18 & -0.00 \\
\hline $\mathrm{DHA}$ & & & 1 & 0.26 & $0.73^{* *}$ & -0.17 & 0.24 & $0.84^{* *}$ \\
\hline $\mathrm{PO}$ & & & & 1 & $0.33^{*}$ & $-0.59^{* *}$ & $0.29^{* *}$ & $0.48^{* *}$ \\
\hline $\mathrm{MBC}$ & & & & & 1 & $-0.40^{* *}$ & $0.63^{* *}$ & $0.82^{* *}$ \\
\hline SOC & & & & & & 1 & $-0.76^{* *}$ & $-0.46^{* *}$ \\
\hline ST & & & & & & & 1 & $0.52^{* *}$ \\
\hline SM & & & & & & & & 1 \\
\hline \multicolumn{9}{|c|}{$10-20 \mathrm{~cm}$} \\
\hline RESP & 1 & -0.26 & $0.72^{* *}$ & $0.51^{* *}$ & $0.86^{* *}$ & $-0.57^{* *}$ & $0.61^{* *}$ & $0.87^{* *}$ \\
\hline BA & & 1 & 0.17 & $-0.47^{* *}$ & -0.00 & $0.65^{* *}$ & $-0.29^{* *}$ & -0.20 \\
\hline $\mathrm{DHA}$ & & & 1 & $0.30^{*}$ & $0.80^{* *}$ & -0.06 & 0.23 & $0.75^{* *}$ \\
\hline $\mathrm{PO}$ & & & & 1 & $0.35^{*}$ & $-0.46^{* *}$ & 0.22 & $0.42^{* *}$ \\
\hline $\mathrm{MBC}$ & & & & & 1 & $0.31^{*}$ & $0.56^{* *}$ & $0.77^{* *}$ \\
\hline SOC & & & & & & 1 & $0.63^{* *}$ & $-0.33^{*}$ \\
\hline ST & & & & & & & 1 & $0.53^{* *}$ \\
\hline SM & & & & & & & & 1 \\
\hline
\end{tabular}



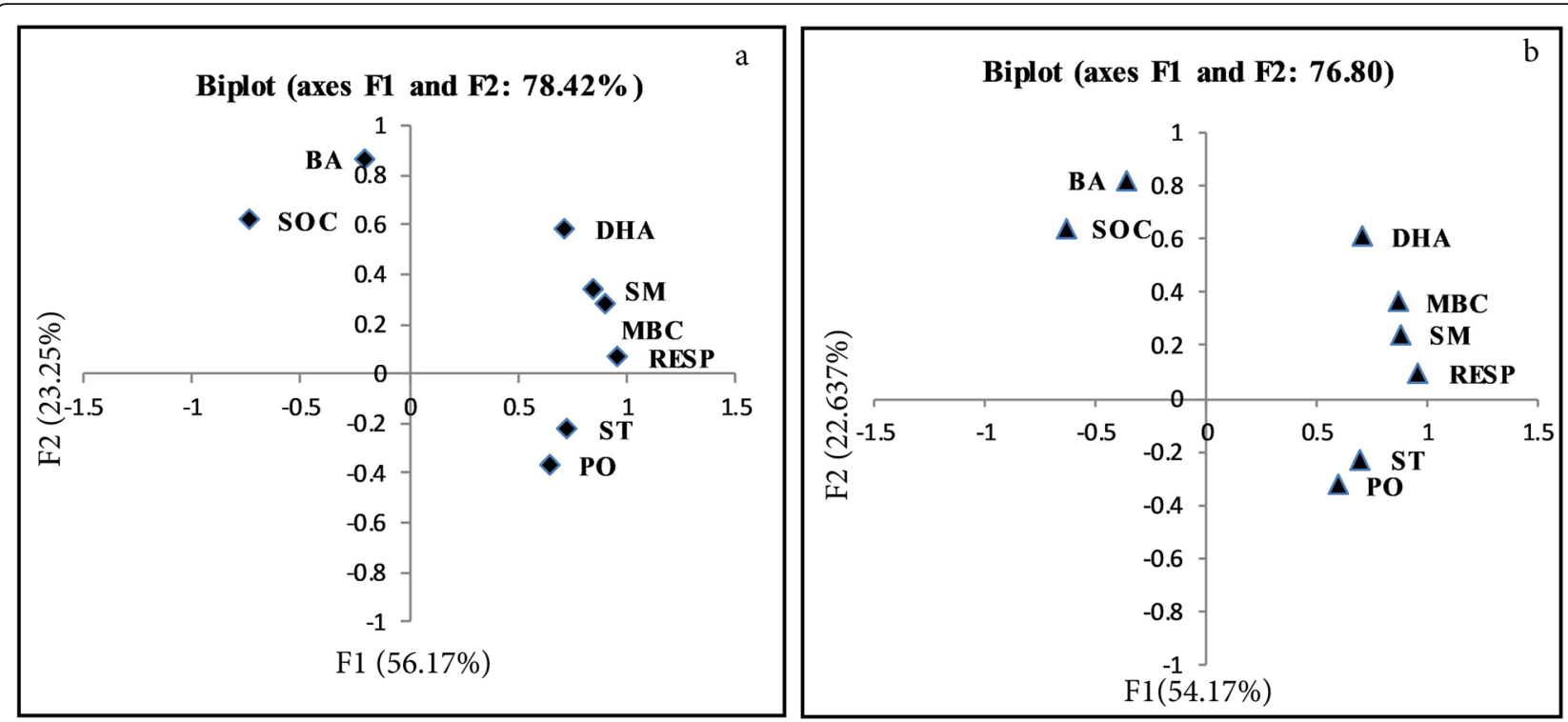

Fig. 7 Principal component analysis of soil moisture, soil temperature, soil respiration, soil enzymes, and microbial biomass carbon in (a) $0-10 \mathrm{~cm}$ and (b) 10-20 cm soil depth. SOC, soil organic carbon; RESP, soil respiration; BA, $\beta$-glucosidase activity; DHA, dehydrogenase activity; PO, phenol oxidase activity; MBC, microbial biomass carbon; ST, soil temperature; SM, soil moisture

Phenol oxidase is considered as an indicator of the breakdown of recalcitrant carbon pool, thereby contributing to heterotrophic soil respiration (Sun et al. 2018). Phenol oxidase is an oxidative enzyme having a key function in lignin decomposition (Grandy et al. 2008). Phenol oxidase activity in the present study fluctuated significantly among the seasons and was found higher in monsoon and post-monsoon seasons. The results are as per the previous study by Zhou and Zhang (2014) who suggested that seasonal variations in oxidative enzyme activity are influenced by soil water content and soil temperature, but it is mainly attributed to seasonal changes in soil moisture. High temperature during premonsoon was not able to induce high oxidative enzyme activity probably due to low moisture content. But, after rainfall events during monsoon, the activity of phenol oxidase increases with an increase in soil moisture. Correlation analysis in our study also indicated that phenol oxidase activity is dependent more on soil moisture than soil temperature. The water limitation may lead to a reduction in enzyme production because of moisture stresses, which include restricted nutrient uptake, mycelium growth, cell proliferation, substratum penetration, and cell desiccation (in extreme cases) (Toberman et al. 2008). As seasonal variation in soil moisture and temperature affects phenol oxidase activity, which is responsible for $\mathrm{C}$ transformation; hence, lignin degradation and $C$ mineralization also vary with soil moisture and temperature (Zhou and Zhang 2014). This can be observed from significant positive correlation of phenol oxidase with soil respiration observed in our study. MBC showed the highest value in monsoon season and lowest in the winter season. It is quite evident that in arid and semi-arid regions, water controls most of the biological processes occurring in soil (Collins et al. 2008). The range of $\mathrm{MBC}$ reported in the present study was 49.8 to 484.52 $\mu \mathrm{g} \mathrm{g}^{-1}$ which falls approximately in reported range (61 to $2000 \mu \mathrm{g} \mathrm{g}^{-1}$ ) by Vance et al. (1987), Henrot and Robertson (1994) for various temperate and tropical forest soils. A similar seasonal pattern in $\mathrm{MBC}$ was reported by Yang et al. (2010) and MBC was reported higher in summer when rainfall was higher. In the present study, the seasonality in MBC was found significantly correlated with soil moisture $\left(R^{2}=0.82 ; p<0.01\right)$ in $0-10 \mathrm{~cm}$ and $\left(R^{2}=0.77 ; p<0.01\right)$ in $10-20 \mathrm{~cm}$ (Table $3)$. Similar results were observed in a pine plantation in the subtropical zone by Chen et al. (2003). A meta-analysis of global MBC across terrestrial ecosystems by $\mathrm{Xu}$ et al. (2013) showed $16.7 \mathrm{Pg} \mathrm{C}$ in the $0-30 \mathrm{~cm}$ of soil. MBC depends greatly on SOC and its availability for microbial activity. In arid and semi-arid conditions, wetting and rewetting cycles were pre-dominant and major part of soil microbial biomass become dormant during the dry period (Lopez-Sangil et al. 2018). However, the rewetting results in an enhancement in MBC as SOC accumulation occurred during the dry period (Xu et al. 2018). In the present study, SOC showed the highest value during the winter season and lowest during the monsoon season. A study by García-Oliva et al. (2003) reported an accumulation of organic matter during the dry period which enhances microbial activity and biomass in the wet season. Our study also presented similar 
results as the accumulation of SOC was observed during the winter season (dry period) which later increased MBC after soil moisture and temperature become optimum for microbial growth. We found a significant negative correlation of $\mathrm{MBC}$ with SOC. SOC is mainly decomposed by soil micro-organisms and reduction in microbial activity results in a decrease in $\mathrm{MBC}$, thereby decreased SOC decomposition rate results in the accumulation of SOC (Shao et al. 2015).

\section{Conclusion}

Seasonality prevailing in Delhi Ridge had a significant influence on MBC and enzymatic activities. All the studied microbiological processes (except $\beta$-glucosidase activity) were found higher in the monsoon season because of optimum moisture and temperature during the period. This can also be observed by a significant positive correlation of $\mathrm{MBC}$ and enzymatic activity (dehydrogenase and phenol oxidase) with soil moisture, which is considered an important factor controlling soil processes occurring in semi-arid conditions. The enzymes considered in our study were involved in $\mathrm{C}$ cycle; thus, it is important in understanding the $\mathrm{C}$ dynamics in such semi-arid forests. The study also focused on correlation among enzyme activities and soil respiration and a significant positive correlation of enzymatic activities (dehydrogenase and phenol oxidase) suggested that they play a significant role in soil respiration. This study enlarges the knowledge about different microbiological processes and their dynamics which are important in understanding their role in $\mathrm{C}$ cycling and $C$ dynamics in semi-arid ecosystems. Although semi-arid land plays a small role in carbon dynamics, globally, it represents one-third of terrestrial habitat and thus sensitive to large-scale environmental changes.

\section{Abbreviations \\ ABTS: 2,2'-azino-bis(3-ethylbenzothiazoline-6-sulphonic acid); BA: $\beta$ - glucosidase activity; C: Carbon; DHA: Dehydrogenase activity; FSI: Forest Survey of India; HCl: Hydrochloric acid; MBC: Microbial biomass carbon; NCT: National capital territory; PC: Principal component; PCA: Principal component analysis; PNG: p-Nitrophenyl- $\beta$-D-glucoside; PNP: p-Nitrophenol; PO: Phenol oxidase activity; RESP: Soil respiration; SM: Soil moisture; SOC: Soil organic carbon; ST: Soil temperature; THAM: Tris-hydroxymethyl aminomethane; TPF: Tri-phenyl formazan; TTC: 2,3,5-triphenyltetrazolium chloride}

\section{Acknowledgements \\ The authors are thankful to the PCCF, Department of Forests and Wildlife, Govt. of NCT of Delhi for the necessary permissions. We also thank Conservation Education Centre, BHNS, Delhi and Late Marshal Vinod Rawat for all the logistics during the study. The authors sincerely thank the reviewers for the thoughtful, positive, and constructive comments which helped to bring the manuscript to its present form.}

\section{Authors' contributions}

RB designed the experiment and methodology, scrutinized the whole data, and helped in writing the manuscript. UT performed the experiment, collected and analyzed the data, and led to the writing of the manuscript.

\section{Funding}

This study was fully funded by Science and Engineering Research Board (SERB), Govt. of India through Project No. SB/YS/LS-88/2013. Additional financial support received from DST Purse grant and R\&D minor grants received from the University of Delhi during the study are also highly acknowledged.

\section{Availability of data and materials}

The datasets analyzed during the current study are not publicly available but are available from the corresponding author on reasonable request.

Ethics approval and consent to participate

No existing ethics and consent of interests.

\section{Consent for publication}

Not applicable.

\section{Competing interests}

The authors declare that they have no competing interests.

Received: 1 June 2020 Accepted: 10 August 2020

Published online: 26 September 2020

\section{References}

Aguilera LE, Gutiérrez JR, Meserve PL (1999) Variation in soil micro-organisms and nutrients underneath and outside the canopy of Adesmia bedwellii (Papilionaceae) shrubs in arid coastal Chile following drought and above average rainfall. J Arid Environ 42:61-70 https://doi.org/10.1006/jare.1999. 0503

Allen SE, Grimshaw HM, Parkinson JA, Quarmby C (1974) Analysis of soils. In: Allen SE (ed) Chemical Analysis of Ecological Materials. Blackwell, Oxford, pp $21-22$

Arunachalam A, Arunachalam K (2000) Influence of gap size and soil properties on microbial biomass in a subtropical humid forest of north-east India. Plant Soil 223:187-195

Austin AT, Yahdjian L, Stark JM, Belnap J, Porporato A, Norton U, Ravetta DA, Schaeffer SM (2004) Water pulses and biogeochemical cycles in arid and semiarid ecosystems. Oecologia 141:221-235 https://doi.org/10.1007/s00442004-1519-1

Baldrian P, Merhautová V, Petránková M, Cajthaml T, Šnajdr J (2010) Distribution of microbial biomass and activity of extracellular enzymes in a hardwood forest soil reflect soil moisture content. Appl Soil Ecol 46(2):177-182 https:// doi.org/10.1016/j.apsoil.2010.08.013

Barbhuiya AR, Arunachalam A, Pandey HN, Arunachalam K, Khan ML, Nath PC (2004) Dynamics of soil microbial biomass C, N and P in disturbed and undisturbed stands of a tropical wet-evergreen forest. Eur J Soil Biol 40(3-4): 113-121

Bastida F, Barberá GG, García C, Hernández T (2008) Influence of orientation, vegetation and season on soil microbial and biochemical characteristics under semiarid conditions. Appl Soil Ecol 38(1):62-70 https://doi.org/10.1016/ j.apsoil.2007.09.002

Bhattacharyya T, Pal DK, Mandal C, Velayutham M (2000) Organic carbon stock in Indian soils and their geographical distribution. Curr Sci 79:655-660

Boerner REJ, Brinkman JA, Smith A (2005) Seasonal variations in enzyme activity and organic carbon in soil of a burned and unburned hardwood forest. Soil Biol Biochem 37:1419-1426 https://doi.org/10.1016/j.soilbio.2004.12.012

Bohlen PJ, Groffman PM, Driscoll CT, Fahey TJ, Siccama TG (2001) Plant-soilmicrobial interactions in a northern hardwood forest. Ecology 82:965-978

Borken W, Davidson EA, Savage K, Gaudinski J, Trumbore SE (2003) Drying and wetting effects on carbon dioxide release from organic horizons. Soil Sci Soc Am J 67:1888-1896 https://doi.org/10.2136/sssaj2003.1888

Carbone MS, Still CJ, Ambrose AR, Dawson TE, Williams AP, Boot CM, Scharffer SM, Schimel JP (2011) Seasonal and episodic moisture controls on plant and microbial contributions to soil respiration. Oecologia 167:265-278 https://doi. org/10.1007/s00442-011-1975-3

Casida LE (1977) Microbial metabolic activity in soil as measured by dehydrogenase determinations. Appl Environ Microbiol 34:630-636

Champion SH, Seth SK (1968) A revised survey of the forest types of India. Govt. of India Press, New Delhi

Chen CR, Xu ZH, Blumfield TJ, Hughes JM (2003) Soil microbial biomass during the early establishment of hoop pine plantation: seasonal variation and 
impacts of site preparation. Forest Ecol Manag 186:213-225 https://doi.org/ 10.1016/S0378-1127(03)00275-5

Collins SL, Sinsabaugh RL, Crenshaw C, Green L, Porras-Alfaro A, Stursova M, Zeglin LH (2008) Pulse dynamics and microbial processes in aridland ecosystems. J Ecol 96:413-420 https://doi.org/10.1111/j.1365-2745.2008.01362.x

Davidson EA, Samanta S, Caramori SS, Savage K (2012) The Dual Arrhenius and Michaelis-Menten kinetics model for decomposition of soil organic matter at hourly to seasonal time scales. Glob Chang Biol 18:371-384 https://doi.org/ 10.1111/j.1365-2486.2011.02546.x

Eivazi F, Tabatabai MA (1990) Factors affecting glucosidase and galactosidase activities in soils. Soil Biol Biochem 22(7):891-897 https://doi.org/10.1016/ 0038-0717(90)90126-K

Eivazi F, Tabatabai MA (1988) Glucosidases and galactosidases in soils. Soil Biol Biochem 20:601-606 https://doi.org/10.1016/0038-0717(88)90141-1

Feng W, Zou X, Schaefer D (2009) Above- and belowground carbon inputs affect seasonal variations of soil microbial biomass in a subtropical monsoon forest of southwest China. Soil Biol Biochem 41:978-983 https://doi.org/10.1016/j. soilbio.2008.10.002

Fierer N, Schimel JP (2002) Effects of drying-rewetting frequency on soil carbon and nitrogen transformations. Soil Biol Biochem 34:777-787 https://doi.org/ 10.1016/50038-0717(02)00007-X

Floch C, Alarcon-Gutiérrez E, Criquet S (2007) ABTS assay of phenol oxidase activity in soil. J Microbiol Meth 71:319-324 https://doi.org/10.1016/j.mimet. 2007.09.020

FSI (2017) The state of forest report. Forest Survey of India, Dehradun

Garcia C, Hernandez T, Costa F, Ceccanti B (1994) Biochemical parameters in soils regenerated by the addition of organic wastes. Waste Manag Res 12:457-466 https://doi.org/10.1177\%2F0734242X9401200602

García-Oliva F, Sveshtarova B, Oliva M (2003) Seasonal effects on soil organic carbon dynamics in a tropical deciduous forest ecosystem in western Mexico. J Trop Ecol 19:179-188 https://doi.org/10.1017/S0266467403003201

Grandy AS, Sinsabaugh RL, Neff JC, Stursova M, Zak DR (2008) Nitrogen deposition effects on soil organic matter chemistry are linked to variation in enzymes, ecosystems and size fractions. Biogeochemistry 91:37-49 https:// doi.org/10.1007/s10533-008-9257-9

Hanson PJ, Edwards NT, Garten CT, Andrews JA (2000) Separating root and soil microbial contributions to soil respiration: a review of methods and observations. Biogeochemistry 48:115-146 https://doi.org/10.1023/A: 1006244819642

Hayano K, Tubaki K (1985) Origin and properties of $\beta$-glucosidase activity of tomato-field soil. Soil Biol Biochem 17:553-557 https://doi.org/10.1016/00380717(85)90024-0

Hedo J, Lucas-Borja ME, Wic-Baena C, Andrés-Abellán M, de las Heras J (2015) Experimental site and season over-control the effect of Pinus halepensis in microbiological properties of soils under semiarid and dry conditions. J Arid Environ 116:44-52 https://doi.org/10.1016/j.jaridenv.2015.01.014

Henrot J, Robertson GP (1994) Vegetation removal in two soils of the humid tropics: effect on microbial biomass. Soil Biol Biochem 26:111-116 https://doi. org/10.1016/0038-0717(94)90202-X

Huxman TE, Snyder KA, Tissue D, Leffler AJ, Ogle K, Pockman WT, Sandquist DR, Potts DL, Schwinning S (2004) Precipitation pulses and carbon fluxes in semiarid and arid ecosystems. Oecologia 141:254-268 https://doi.org/10. 1007/s00442-004-1682-4

Iqbal J, Hu R, Feng M, Lin S, Malghani S, Ali IM (2010) Microbial biomass, and dissolved organic carbon and nitrogen strongly affect soil respiration in different land uses: a case study at Three Gorges Reservoir Area, South China. Agric Ecosyst Environ 137:294-307 https://doi.org/10.1016/j.agee.2010.02.015

Jin Z, Qi Y, Dong Y (2007) Diurnal and seasonal dynamics of soil respiration in desert shrubland of Artemisia ordosica on Ordos Plateau of Inner Mongolia. China. J For Res 18:231-235 https://doi.org/10.1007/s11276-007-0047-3

Kishimoto-Mo AW, Yonemura S, Uchida M, Kondo M, Murayama S, Koizumi H (2015) Contribution of soil moisture to seasonal and annual variations of soil $\mathrm{CO}_{2}$ efflux in a humid cool-temperate oak-birch forest in central Japan. Ecol Res 30:311-325 https://doi.org/10.1007/s11284-015-1254-6

Lawrence CR, Neff JC, Schimel JP (2009) Does adding microbial mechanisms of decomposition improve soil organic matter models? A comparison of four models using data from a pulsed rewetting experiment. Soil Biol Biochem 41:1923-1934 https://doi.org/10.1016/.jsoilbio.2009.06.016

Li Y, Zhang L, Fang S, Tian Y, Guo J (2018) Variation of soil enzyme activity and microbial biomass in poplar plantations of different genotypes and stem spacings. J For Res 29:963-972 https://doi.org/10.1007/s11676-017-0524-2
Liu Y, Li S, Sun X, Yu X (2016) Variations of forest soil organic carbon and its influencing factors in east China. Ann For Sci 73(2):501-511 https://doi.org/ 10.1007/s13595-016-0543-8

Lopez-Sangil L, Hartley IP, Rovira P, Casals P, Sayer EJ (2018) Drying and rewetting conditions differentially affect the mineralization of fresh plant litter and extant soil organic matter. Soil Biol Biochem 124:81-89 https://doi.org/10. 1016/j.soilbio.2018.06.001

Lou Y, Li Z, Zhang T, Liang Y (2004) $\mathrm{CO}_{2}$ emissions from subtropical arable soils of China. Soil Biol Biochem 36:1835-1842 https://doi.org/10.1016/j.soilbio. 2004.05.006

Luo L, Gu JD (2015) Seasonal variability of extracellular enzymes involved in carbon mineralization in sediment of a subtropical mangrove wetland. Geomicrobiol J 32(1):68-76 https://doi.org/10.1080/01490451.2014.925012

Maithani K, Tripathi RS, Arunachalam A, Pandey HN (1996) Seasonal dynamics of microbial biomass $\mathrm{C}, \mathrm{N}$ and $\mathrm{P}$ during regrowth of a disturbed subtropical humid forest in north-east India. Appl Soil Ecol 4:31-37 https://doi.org/10. 1016/0929-1393(96)00101-1

Mall RK, Gupta A, Singh R, Singh RS, Rathore LS (2006) Water resources and climate change: an Indian perspective. Curr Sci:1610-1626

Meena A, Hanief M, Dinakaran J, Rao KS (2020) Soil moisture controls the spatiotemporal pattern of soil respiration under different land use systems in semiarid ecosystems of Delhi, India. Ecol Process 9:15 https://doi.org/10.1186/ s13717-020-0218-0

Memoli V, Esposito F, De Marco A, Arena C, Vitale L, Tedeschi A, Magliulo V, Maisto G (2017) Metal compartmentalization in different biomass portions of Helianthus annuus $\mathrm{L}$. and Sorghum bicolor L. grown in an agricultural field inside an urban fabric. Appl Soil Ecol 121:118-126 https://doi.org/10.1016/.japsoil.2017.09.035

Milly PCD, Wetherald RT, Dunne KA, Delworth TL (2002) Increasing risk of great floods in a changing climate. Nature 415:514-517 https:/doi.org/10.1038/415514a

Mori T, Wachrinrat C, Staporn D, Meunpong P, Suebsai W, Boonsri K, Kitayama K (2016) Seasonal changes in soil respiration and microbial biomass in five tropical tree plantations in Thailand. Tropics 25:85-99 https://doi.org/10.3759/ tropics.MS15-18

Nannipieri P, Grego S, Ceccanti B, Bollag J, Stotzky G (1990) Ecological significance of the biological activity in soil. In: Bollag JM, Stotzky G (eds). Soil Biochem 6:293-355

Panico SC, Esposito F, Memoli V, Vitale L, Polimeno F, Magliulo V, Maisto G, De Marco A (2020) Variations of agricultural soil quality during the growth stages of sorghum and sunflower. Appl Soil Ecol 152:103569 https://doi.org/ 10.1016/j.apsoil.2020.103569

Peterson BJ, Holmes RM, McClelland JW, Vörösmarty CJ, Lammers RB, Shiklomanov Al et al (2002) Increasing river discharge to the Arctic Ocean. Science 298:2171-2173 https://doi.org/10.1126/science.1077445

Placella SA, Brodie EL, Firestone MK (2012) Rainfall-induced carbon dioxide pulses result from sequential resuscitation of phylogenetically clustered microbial groups. PNAS 109:10931-10936 https://doi.org/10.1073/pnas.1204306109

Qi L, Yang J (2017) Microbial community composition regulates SOC decomposition response to forest conversion in a Chinese temperate forest. Ecol Res 32:163-172 https://doi.org/10.1007/s11284-016-1428-x

Ros M, Hernandez MT, Garcia C (2003) Soil microbial activity after restoration of a semiarid soil by organic amendments. Soil Biol Biochem 35:463-469 https:// doi.org/10.1016/50038-0717(02)00298-5

Ross DJ, Speir TW, Kettles HA, Mackay AD (1995) Soil microbial biomass, C and N mineralization and enzyme activities in a hill pasture: influence of season and slow-release P and S fertilizer. Soil Biol Biochem 27:1431-1443

Ruan HH, Zou XM, Scatena FN, Zimmerman JK (2004) Asynchronous fluctuation of soil microbial biomass and plant litterfall in a tropical wet forest. Plant Soil 260:147-154 https://doi.org/10.1023/B:PLSO.0000030177.20951.94

Ryan MG, Law BE (2005) Interpreting, measuring, and modeling soil respiration. Biogeochemistry 73:3-27 https://doi.org/10.1007/s10533-004-5167-7

Salazar A, Sulman BN, Dukes JS (2018) Microbial dormancy promotes microbial biomass and respiration across pulses of drying-wetting stress. Soil Biol Biochem 116:237-244 https://doi.org/10.1016/j.soilbio.2017.10.017

Salazar S, Sánchez LE, Alvarez J, Valverde A, Galindo P, Igual JM et al (2011) Correlation among soil enzyme activities under different forest system management practices. Ecol Eng 37(8):1123-1131

Schimel DS (1995) Terrestrial ecosystems and the carbon cycle. Glob Chang Biol 1(1):77-91 https://doi.org/10.1111/j.1365-2486.1995.tb00008x

Shao X, Yang W, Wu M (2015) Seasonal dynamics of soil labile organic carbon and enzyme activities in relation to vegetation types in Hangzhou Bay tidal flat wetland. PLoS One 10:e0142677 https://doi.org/10.1371/journal.pone.0142677 
Singh JS, Raghubanshi AS, Singh RS, Srivastava SC (1989) Microbial biomass acts as a source of plant nutrients in dry tropical forest and savanna. Nature 338:499-500

Smith JL, Papendick Rl, Bezdicek DF, Lynch JM (1992) Soil organic matter dynamics and crop residue management. In: Metting FB Jr (ed) Soil microbial ecology. Dekker, New York, pp 65-93

Song Y, Song C, Yang G, Miao Y, Wang J, Guo Y (2012) Changes in labile organic carbon fractions and soil enzyme activities after marshland reclamation and restoration in the Sanjiang Plain in Northeast China. Environ Manage 50:418426 https://doi.org/10.1007/s00267-012-9890-x

Stocker T (2014) Climate change 2013: the physical science basis: Working Group I contribution to the Fifth assessment report of the Intergovernmental Panel on Climate Change. Cambridge University Press, Cambridge

Sun Q, Wang R, Wang Y, Du L, Zhao M, Gao X, Hu Y, Guo S (2018) Temperature sensitivity of soil respiration to nitrogen and phosphorous fertilization: does soil initial fertility matter? Geoderma 325:172-182 https://doi.org/10.1016/j. geoderma.2018.04.001

Tang X, Liu S, Zhou G, Zhang D, Zhou C (2006) Soil-atmospheric exchange of $\mathrm{CO}_{2}, \mathrm{CH}_{4}$, and $\mathrm{N}_{2} \mathrm{O}$ in three subtropical forest ecosystems in southern China. Glob Chang Biol 12:546-560 https://doi.org/10.1111/j.1365-2486.2006.01109.x

Toberman H, Evans CD, Freeman C, Fenner N, White M, Emmett BA, Artz RR (2008) Summer drought effects upon soil and litter extracellular phenol oxidase activity and soluble carbon release in an upland Calluna heathland. Soil Biol Biochem 40:1519-1532 https://doi.org/10.1016/j.soilbio.2008.01.004

Tomar U, Baishya R (2019) Moisture regime influence on soil carbon stock and carbon sequestration rates in semi-arid forests of the National Capital Region. India. J For Res https://doi.org/10.1007/s11676-019-01032-6

Uhlirova E, Elhottova D, Triska J, Nantruckova H (2005) Physiology and microbial community structure in soil at extreme water content. Folia Microbiol 50(2): $161-166$

Van Hees PA, Jones DL, Finlay R, Godbold DL, Lundström US (2005) The carbon we do not see-the impact of low molecular weight compounds on carbon dynamics and respiration in forest soils: a review. Soil Biol Biochem 37:1-13 https://doi.org/10.1016/j.soilbio.2004.06.010

Vance ED, Brookes PC, Jenkinson DS (1987) An extraction method for measuring soil microbial biomass C. Soil Biol Biochem 19:703-707 https://doi.org/10. 1016/0038-0717(87)90052-6

Wall A, Heiskanen J (2003) Water-retention characteristic and related physical properties of soil on afforested agricultural land in Finland. Forest Ecol Manag 186:21-32

Wang Q, Xiao F, He T, Wang S (2013) Responses of labile soil organic carbon and enzyme activity in mineral soils to forest conversion in the subtropics. Ann For Sci 70(6):579-587

Wang R, Filley TR, Xu Z, Wang X, Li MH, Zhang Y, Luo W, Jiang Y (2014) Coupled response of soil carbon and nitrogen pools and enzyme activities to nitrogen and water addition in a semi-arid grassland of Inner Mongolia. Plant Soil 381(1-2):323-336 https://doi.org/10.1007/s11104-014-2129-2

Wardle DA (1992) A comparative assessment of factors which influence microbial biomass carbon and nitrogen levels in soil. Biol Rev 67:321-358 https://doi. org/10.1111/j.1469-185X.1992.tb00728.X

Wei H, Chen X, Xiao G, Guenet B, Vicca S, Shen W (2015) Are variations in heterotrophic soil respiration related to changes in substrate availability and microbial biomass carbon in the subtropical forests? Sci Rep 5:18370 https:// doi.org/10.1038/srep18370

Wick B, Kühne RF, Vielhauer K, Vlek PL (2002) Temporal variability of selected soil microbiological and biochemical indicators under different soil quality conditions in south-western Nigeria. Biol Fert Soils 35(3):155-167

Wieder WR, Bonan GB, Allison SD (2013) Global soil carbon projections are improved by modelling microbial processes. Nat Clim Chang 3:909 https:// doi.org/10.1038/nclimate1951

Wolinska A, Stępniewska Z (2012) Dehydrogenase activity in the soil environment. In: Canuto RA (ed) Dehydrogenases. Intech, Rijeka, pp 183-209

Wu JJ, Joergensen RG, Pommerening B, Chaussod R, Brookes PC (1990) Measurement of soil microbial biomass $C$ by fumigation-extraction - an automated procedure. Soil Biol Biochem 22:1167-1169 https://doi.org/10. 1016/0038-0717(90)90046-3

Xu L, Baldocchi DD, Tang J (2004) How soil moisture, rain pulses, and growth alter the response of ecosystem respiration to temperature. Global Biogeochem Cycles 18:GB4002 https://doi.org/10.1029/2004GB002281

Xu X, Thornton PE, Post WM (2013) A global analysis of soil microbial biomass carbon, nitrogen and phosphorus in terrestrial ecosystems. Glob Ecol Biogeogr 22(6):737-749 https://doi.org/10.1111/geb.12029
Xu Y, Seshadri B, Sarkar B, Rumpel C, Sparks D, Bolan NS (2018) Microbial control of soil carbon turnover. In: The Future of Soil Carbon: Its Conservation and Formation, pp 165-194 https://doi.org/10.1016/B978-0-12-811687-6.00006-7

Yang K, Zhu J, Zhang M, Yan Q, Sun OJ (2010) Soil microbial biomass carbon and nitrogen in forest ecosystems of Northeast China: a comparison between natural secondary forest and larch plantation. J Plant Ecol 3:175-182 https:// doi.org/10.1093/jpe/rtq022

Zhang N, He X-D, Gao Y-B, Li Y-H, Wang H-T, Ma D, Zhang R, Yang S (2010) Pedogenic carbonate and soil dehydrogenase activity in response to soil organic matter in Artemisia ordosica community. Pedosphere 20(2):229-235

Zhou X, Zhang Y (2014) Temporal dynamics of soil oxidative enzyme activity across a simulated gradient of nitrogen deposition in the Gurbantunggut Desert, Northwestern China. Geoderma 213:261-267 https://doi.org/10.1016/j. geoderma.2013.08.030

\section{Publisher's Note}

Springer Nature remains neutral with regard to jurisdictional claims in published maps and institutional affiliations.

\section{Submit your manuscript to a SpringerOpen ${ }^{\circ}$ journal and benefit from:}

- Convenient online submission

- Rigorous peer review

- Open access: articles freely available online

High visibility within the field

- Retaining the copyright to your article

Submit your next manuscript at $\boldsymbol{\sim}$ springeropen.com 